\title{
Foraminiferal response to environmental changes in Kiel Fjord, SW Baltic Sea
}

\author{
A. Nikulina, I. Polovodova, and J. Schönfeld \\ Leibniz-Institute for Marine Sciences IFM-GEOMAR, Wischhofstr. 1-3, 24148 Kiel, Germany \\ Received: 1 November 2007 - Published in eEarth Discuss.: 3 December 2007 \\ Revised: 5 June 2008 - Accepted: 22 July 2008 - Published: 12 August 2008
}

\begin{abstract}
The living benthic foraminiferal assemblages in Kiel Fjord (SW Baltic Sea) were investigated in the years 2005 and 2006. The faunal studies were accomplished by geochemical analyses of surface sediments. In general, sediment pollution by copper, zinc, tin and lead is assessed as moderate in comparison with levels reported from other areas of the Baltic Sea. However, the inner Kiel Fjord is still exposed to a high load of metals and organic matter due to enhanced accumulation of fine-grained sediments in conjunction with potential pollution sources as shipyards, harbours and intensive traffic. The results of our survey show that the dominant environmental forcing of benthic foraminifera is nutrients availability coupled with human impact. A comparison with faunal data from the 1960s reveals apparent changes in species composition and population densities. The stress-tolerant species Ammonia beccarii invaded Kiel Fjord. Ammotium cassis had disappeared that reflects apparently the changes in salinity over the last 10 years. These changes in foraminiferal community and a significant increase of test abnormalities indicate an intensified environmental stress since the 1960 s.
\end{abstract}

\section{Introduction}

The previous studies in the Kiel Bight only gave a very short description of foraminiferal distribution, though they were started in 19th century (Möbius, 1888). Ecological observations of foraminifera were initiated by Rhumbler (1935), who used rather descriptive than quantitative methods of investigation. Next, Rottgardt (1952) distinguished three different foraminiferal assemblages in the Baltic Sea, which are distributed according to the salinity pattern: marine,

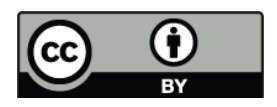

Correspondence to: A. Nikulina (anikoulina@ifm-geomar.de) brackish-marine (fjords and shallow areas of the Kiel Bight), and brackish faunas. A detailed taxonomical and ecological overview on benthic foraminifera in the south-western Baltic Sea was provided by Lutze (1965), who found out that temperature and salinity rather than substrate were the main ecological controls on foraminiferal distribution in this area. Vice versa, Wefer (1976) observed that the abundances of foraminifera in sediments off Bokniseck (open Kiel Bight) were regulated by substrate features, hydrodynamics and oxygen content of the bottom water. Foraminiferal food preferences in the open Kiel Bight were described by Schönfeld and Numberger (2007b), who reported two reproduction events of Elphidium excavatum clavatum following the spring bloom and suggested the "bloom-feeding" strategy of this species.

The benthic foraminiferal distribution in Kiel Fjord has been left out of sight, with the exception of 4 stations investigated by Lutze in 1962-1963, which were taken as reference points for our study. Over the 20th century, Kiel Fjord has experienced a strong anthropogenic impact. For monitoring purposes, the foraminiferal response to environmental changes attracts attention under the aspect of rising ecological problems.

A number of studies addressed the foraminiferal reactions to changing environmental parameters as salinity, temperature, oxygen, food availability, pH, (e.g. Bradshaw, 1957, 1961; Boltovskoy et al., 1991; Moodley and Hess, 1992; Alve and Murray, 1999; Stouff et al., 1999a, b; Gustafsson and Nordberg 2001; Le Cadre and Debenay, 2003), contamination by trace metals (Ellison et al., 1986; Sharifi et al., 1991; Alve, 1991; Alve and Olsgardt, 1999; Yanko et al., 1998; Debenay et al., 2001) and sewage effluents (e.g. Watkins, 1961; Schafer, 1973; Tomas et al., 2000). A decrease of population density, reproduction capability, enhanced mortality, and increasing frequency of test abnormalities were observed under the high trace metal or organic matter levels (Schafer, 1973; Samir and El Din, 2001; Bergin et

Published by Copernicus Publications on behalf of the European Geosciences Union. 


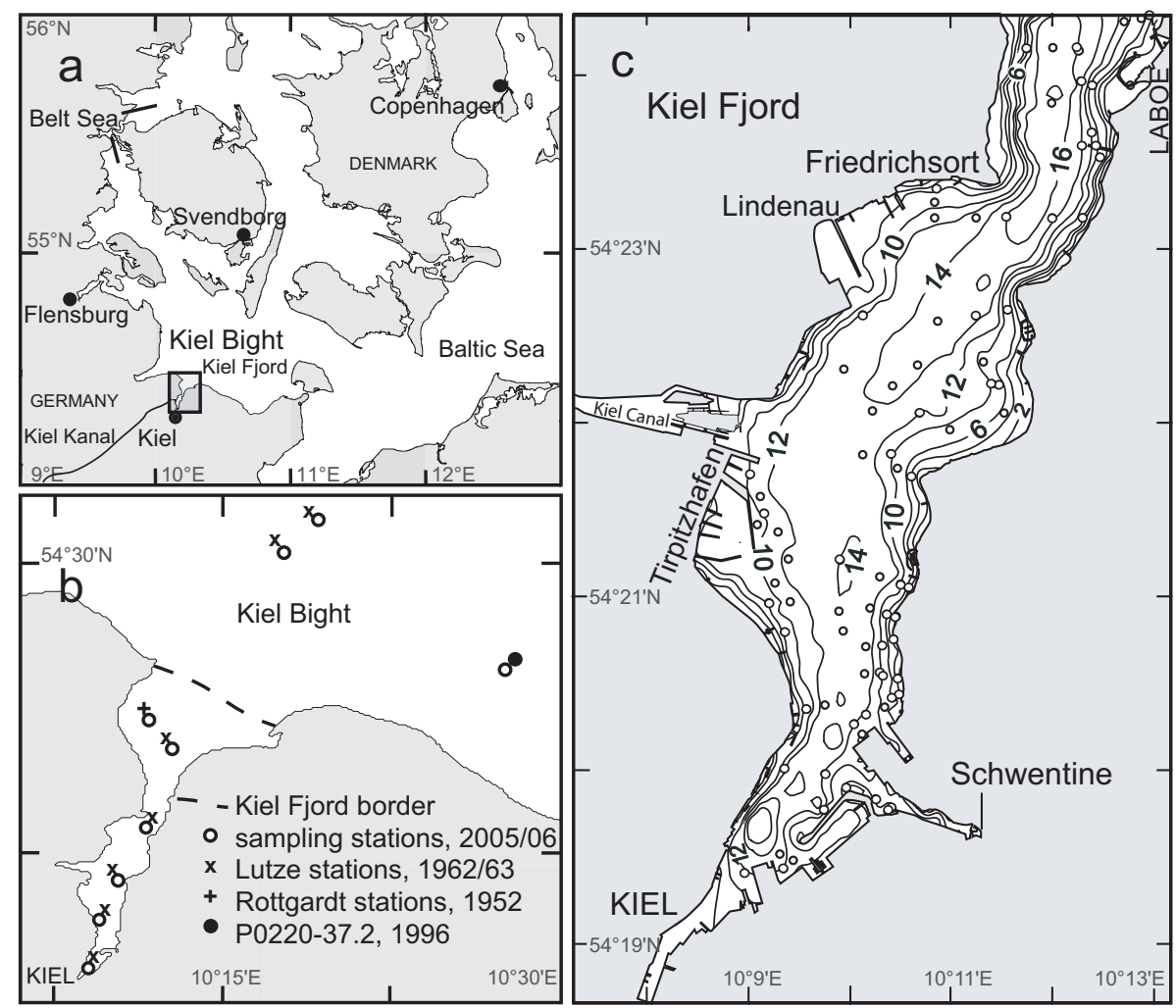

Fig. 1. Study area: (a) SW Baltic Sea, (b) outer Kiel Fjord, (c) inner Kiel Fjord with bathymetry $(m)$. Circles indicate here the sampling stations. For station description see also Supplementary material (http://www.electronic-earth.net/3/37/2008/ee-3-37-2008-supplement.pdf, Table 1).

al., 2006; Burone et al., 2006; Ernst et al., 2006; Di Leonardo et al., 2007). On the other hand, it was shown that population density of foraminifera may increase in vicinity of sewage outfalls (Watkins, 1961; Tomas et al., 2000). Culture experiments revealed that $A$. beccarii produces abnormal chambers at 10-20 $\mu \mathrm{g} / \mathrm{l}$ of copper in seawater (Sharifi et al., 1991; Le Cadre and Debenay, 2006) and dies at concentrations exceeding $200 \mu \mathrm{g} / \mathrm{l}$ (Le Cadre and Debenay, 2006). Therefore, foraminifera appear to be a rather sensitive tool for the monitoring of pollution, though should be used with caution, because their distribution is determined by numerous environmental variables (Alve and Olsgardt; Stouff et al., 1999a, b; 1999; Le Cadre and Debenay, 2006).

The aim of this study was (1) to describe the distribution of living (stained) benthic foraminifera in the Kiel Fjord, (2) to investigate the distribution pattern of main geochemical parameters of surface sediments, (3) to outline the level of pollution by trace metals, and (4) to assess the foraminiferal response to environmental changes during the past decades.

\section{Study area}

Kiel Fjord is a $9.5 \mathrm{~km}$ long, N-S extending and narrow inlet of southwestern Kiel Bight $\left(54^{\circ} 19^{\prime}-54^{\circ} 30^{\prime} \mathrm{N} ; 10^{\circ} 06^{\prime}-\right.$ $10^{\circ} 22^{\prime} \mathrm{E}$ ). The Friedrichsort Sound divides the fjord into a southern, inner fjord with width to $250 \mathrm{~m}$, and a northern, outer fjord, which expands up to $7.5 \mathrm{~km}$ and passes into Kiel Bight (Fig. 1). The inner Kiel Fjord is mostly 10 to $12 \mathrm{~m}$ deep. A system of up to $16 \mathrm{~m}$ deep channels connects the inner with the outer fjord. The outer fjord itself is more than $20 \mathrm{~m}$ deep.

As the entire Kiel Fjord is relatively shallow and isolated, its hydrographical characteristics weakly depend on the saltrich inflow water from the Belt Sea. The only river discharging fresh water into Kiel Fjord is the Schwentine.

The water masses of the inner fjord are homogenously mixed, except during summer. Then, surface water has a temperature up to $16^{\circ} \mathrm{C}$ and a salinity of about 14 units. The underlying deep water has a temperature of about $12^{\circ} \mathrm{C}$ and a salinity of up to 21 units. In winter, the temperature does not change significantly with depth and may decrease to $2^{\circ} \mathrm{C}$. The salinity is constant with depth as well (Schwarzer and Themann, 2003).

Coastal and near-shore erosion of Pleistocene till is the most important source of sediment in this area. Lag sediments with coarse sand and gravel prevail in the shallow coastal areas. They pass into sandy muds and silts in the deeper basins. In the innermost fjord, dark organic-rich 
muds are encountered even in shallow areas. Sand veneers are found in the Friedrichsort Sound due to relatively strong currents between inner and outer fjord (Schwarzer and Themann, 2003).

Kiel Fjord has seen a strong anthropogenic impact for the last 70 years by town infrastructure, shipyards, military and sport harbours and the intense traffic through Kiel Canal. The shipbuilding industry has led to a substantial trace metal pollution in places. Dredging to keep the seaways clear, and the ship traffic itself have caused a strong disturbance of surface sediments.

\subsection{Previous pollution surveys}

Despite the long-term anthropogenic load in study area, reports on the early history of pollution of Kiel Fjord are rare. Recently, the monitoring of metals concentration at a few stations in Kiel Bight by the Institute for Marine Research, Warnemünde (IOW) indicates no significant temporal trend in trace metal content for 1998-2000 with respect to the observed high interannual variability (e.g. Nausch et al., 2003b; Pohl et al., 2005). Kiel Fjord itself is considered by LANU (The Regional Environmental Protection Agency of the Bundesland Schleswig-Holstein) as one of the most important local hot spots of cadmium, lead, copper, and zinc contamination in the coastal waters of Schleswig-Holstein. In the year 2000 for instance, the concentrations of $\mathrm{Cu}, \mathrm{Zn}$ and $\mathrm{Pb}$ in sediment fraction $<20 \mu \mathrm{m}$ were 82,300 and $130 \mathrm{mg} / \mathrm{kg}$ in the inner fjord correspondingly (Haarich et al., 2003), whereas in outer fjord $\mathrm{Cu}, \mathrm{Zn}$ and $\mathrm{Pb}$ content was estimated to 30 , 210 and $60 \mathrm{mg} / \mathrm{kg}$, respectively (LANU archive: Ostseemonitoring Programme). No clear temporal trend of metals concentrations in 1995-2004 was observed in sediments of Kiel Fjord. Extremely high concentrations of organically bound tin $(407-2556 \mu \mathrm{g}$ TBT-Sn/kg) were found in the fjord sediments; they are supposed to cause the aberrant changes in reproduction system of the periwinkle (LANU, 2001). High concentrations of $\mathrm{Cu}$ and $\mathrm{Zn}$ were found in fish (Senocak, 1995) and mussels (ter Jung, 1992) from the inner Kiel Fjord. But the organisms in the outer fjord showed the lowest metals content for all Schleswig-Holstein waters.

Kiel Fjord has been affected by eutrophication induced by a high load of nutrient and organic carbon from the city and surrounding area (Gerlach, 1984). Herein, the nutrient concentrations and primary production showed a southward increase to the inner fjord (Schiewer and Gocke, 1995). The construction of a central treatment plant (Bülk, Klärwerk) in 1972 has reduced the input of nitrogen and phosphorus significantly (Kallmeyer, 1997; Rheinheimer, 1998), but the deep-water oxygenation improved not early than in the 1990s (Gerlach, 1996; Haarich et al., 2003; LANU, 2003). Nevertheless, oxygen deficiency may occur at specific weather conditions in the fjord regularly in late summer due to a stable water stratification (Gerlach, 1990).

\section{Material and methods}

\subsection{Sampling}

This study is based on 89 surface sediment samples collected at 4.5-18.1 m water depth between December 2005 and May 2006 on seven daily cruises with R/V Polarfuchs. The samples were retrieved with a Rumohr corer with a plastic tube of $55 \mathrm{~mm}$ inner diameter and a Van-Veen Grab. The latter was used when sandy sediments were encountered. The Ruhmor corer was deployed three times at each station in order to avoid errors associated with spatial patchiness. The uppermost centimeter of the sediment was removed on each deployment with a spoon, and with cut-off syringes when a Van-Veen Grab was used. The sediment was placed into a glass vial, thoroughly mixed, and subsamples for geochemical analyses were taken from this mixture at first. The remaining sample was transferred to a PVC vial, and preserved and stained with a solution of $2 \mathrm{~g}$ Rose Bengal per litre ethanol in order to mark foraminifers living at the time of sampling (Murray and Bowser, 2000).

\subsection{Hydrographic measurements}

The salinity, temperature and dissolved oxygen content of the overlying water in the Rumohr corer tube was measured on board with Oxi- and Conductivity meters (WTW Oxi323/325 and LF320). As the measurements were made within minutes after retrieval, and air temperatures were not substantially higher than the water temperatures, we consider these values as representative for the near-bottom water. In the Schwentine river mouth, at three stations CTD-profiles were done with WTW Profiline 197 TS in 1-m intervals to locate the boundary between riverine fresh water and higher- saline fjord waters.

\subsection{Geochemical analysis}

Subsamples for geochemical analysis were freeze-dried and powdered in an agate mortar. Measurements of $\mathrm{C}_{\text {org }}$, total carbon (TC) and total nitrogen (TN) were performed with a Carlo Erba NA-1500-CNS analyzer at IFM-GEOMAR with accuracy better than $\pm 1.5 \%$. Chlorophyll- $a$ and phaeopigments were determined after acetone extraction with a Turner TD-700 Fluorometer at IFM-GEOMAR. The precision of the method is $\pm 10 \%$. Biogenic silica (opal) measurements were done according to an automated leaching method for the analysis of $\mathrm{SiO}_{2}$ in sediments and particulate matter described by Müller and Schneider (1993) using a Skalar 6000 photometer with precision $\pm 1 \%$. For trace metal analyses, the sediment samples were digested in an $\mathrm{HNO}_{3}$-HF$\mathrm{HClO}_{4}-\mathrm{HCl}$ mixture solution. The solution was diluted and measurements were performed with an AGILENT 7500cs ICP-MS at the Institute of Geosciences, University of Kiel (Garbe-Schönberg, 1993). Blanks and the international standard MAG-1 were repeatedly analyzed together with the 
samples in order to evaluate the precision and accuracy of the measurements. The accuracy of analytical results as estimated from replicate standard measurements was better than $\pm 1.5 \%$.

\subsection{Foraminiferal studies}

The sub-samples for foraminiferal analysis were stored in a fridge for two weeks to effect a sufficient staining with Rose Bengal. The samples were first passed through a $2000 \mu \mathrm{m}$ screen in order to remove molluscs' shells or pebbles, and then gently washed through a $63-\mu \mathrm{m}$ sieve. Sediments of the Baltic Sea have a high content of organic detritus. After drying, the detritus creates a film layer on the sample, which has to be disintegrated before picking (Lutze, 1965). In order to achieve a separation of the organic detritus, the 63$2000 \mu \mathrm{m}$ size fraction was transferred into a cylinder with some tap water and left for a while. Then the supernatant water was poured through a filter paper to collect the suspended organic debris. During drying, the organic flocks stuck to the filter paper and foraminiferal tests could be easily brushed off (Lehmann and Röttger, 1997). The 63-2000 $\mu \mathrm{m}$ and $>2000 \mu \mathrm{m}$ fractions were dried at $60^{\circ} \mathrm{C}$, weighed, and splitted. Well-stained foraminifers that were considered as living at the time of sampling were picked from respective aliquots, sorted at species level, mounted in Plummer cell slides and counted. Both normal and abnormal tests were counted separately. The standing stock was expressed as number of specimens per $10 \mathrm{~cm}^{3}$ of sediment. The main species were photographed with Cam Scan Scanning Electronic Microscope at the Institute of Geosciences, Kiel University.

\section{Results and discussion}

\subsection{Hydrography}

The temperature and salinity of near-bottom water in Kiel Fjord showed a pronounced seasonality. Temperature decreased from $8^{\circ} \mathrm{C}$ on average in December 2005 to $2^{\circ} \mathrm{C}$ in February, and raised again to $7^{\circ} \mathrm{C}$ in May 2006. In December 2005, the near-bottom water showed the highest salinity with 23.2 units and minimum values of 16.5 units in May.

In the Schwentine river mouth, the boundary layer between riverine fresh water and saline fjord water was encountered at approximately $1 \mathrm{~m}$ depth in February. With an average discharge of $7.3 \mathrm{~m}^{3} / \mathrm{s}$ (Schulz, 2000), the Schwentine substantially freshens the waters of the inner fjord.

The oxygen concentration mostly exceeded $400 \mu \mathrm{mol} / 1$ and decreased slightly only in the deep basins. The saturation levels varied from $58 \%$ to $100 \%$. As such, a sincere oxygen deficiency in the near-bottom waters of Kiel Fjord was not recognized.

The oxygen content of near-surface sediments was measured with a Unisense microelectrode (Revsbech, 1989) in a short core taken from the inner fjord at the beginning of
December 2005. The overlying water had oxygen saturation $71 \%$; the sediments were muddy-sand. At $1 \mathrm{~mm}$ sediment depth, the oxygen saturation was still more than 50\%, and a zero oxygen level was encountered at $3.5 \mathrm{~mm}$. As compared with a usual 2 to $5 \mathrm{~cm}$ thick oxic layer in normal marine settings, the oxygenated surface layer in this core was quite thin.

\subsection{Organic carbon and $\mathrm{C} / \mathrm{N}$ ratio}

The organic carbon content in the surface sediments ranged from 1\% in Friedrichsort Sound to $7.8 \%$ in muddy sediments of the inner fjord (Fig. 2), and it is negatively correlated with the sand content $(r=0.793, n=89)$. Though the changes in mean $\mathrm{C}_{\text {org }}$ values through the year were not substantial, we observed an increased $\mathrm{C}_{\text {org }}$ content associated with the spring bloom in February and March (Graf et al., 1982; Wasmund et al., 2005). Generally, the $C_{\text {org }}$ content was higher than reported by Leipe et al. (1998) for the open Mecklenburg and Kiel Bights (5\% for the fine fraction).

The mean $\mathrm{C} / \mathrm{N}$ ratio depicts a substantial input of organic matter from the hinterland (Fig. 2). The $\mathrm{C} / \mathrm{N}$ ratio increases southwards from 4 in the outer fjord to 15 in the inner fjord, which is in the range of values for the southern Baltic Sea (Pertillä et al., 2003). Seasonally, the $\mathrm{C} / \mathrm{N}$ ratio changed not significantly but has the lower values in February-March that probably mirrors the accumulation of fresh detritus characterized by low $\mathrm{C} / \mathrm{N}$ values of 5.6 to 7 (Graf et al., 1982).

\subsection{Biogenic silica}

Biogenic silica (opal) content in surface sediments of Kiel Fjord was higher in spring as compared to December (0.1 wt.\% to $8 \mathrm{wt} . \%)$, and showed a maximum in the inner fjord (Fig. 2). The maximum of diatom biomass and biogenic silica flux to the sea floor was recorded in early April in the SW Baltic Sea (Wasmund et al., 2005, 2006). Apparently, the increase of opal in sediments of Kiel Fjord in February reflected the spring bloom of diatoms in late February and March. Surface sediment biogenic silica content clearly reflects spatial differences in surface water primary productivity, and at low depths and under relatively high sedimentation rates, it could refer to seasonal changes of primary productivity (Rathburn et al., 2001; Bernardez et al., 2006). At the same time, Schwentine river might also be a source of opal for the inner fjord sediments because in the suspension of its water the opal values exceeded $15 \mathrm{wt} . \%$ owing to freshwater diatoms. As the maximum of biogenic silica in the inner fjord sediments was not found in the vicinity of Schwentine mouth, we consider the primary productivity in the fjord as the main cause of seasonal and spatial variations in biogenic silica concentrations.

\subsection{Chlorine and phaeopigments}

Chlorine concentrations in surface sediments varied from 7000 to $600000 \mathrm{ng} / \mathrm{g}$ dry sediment (Fig. 2). The values were 

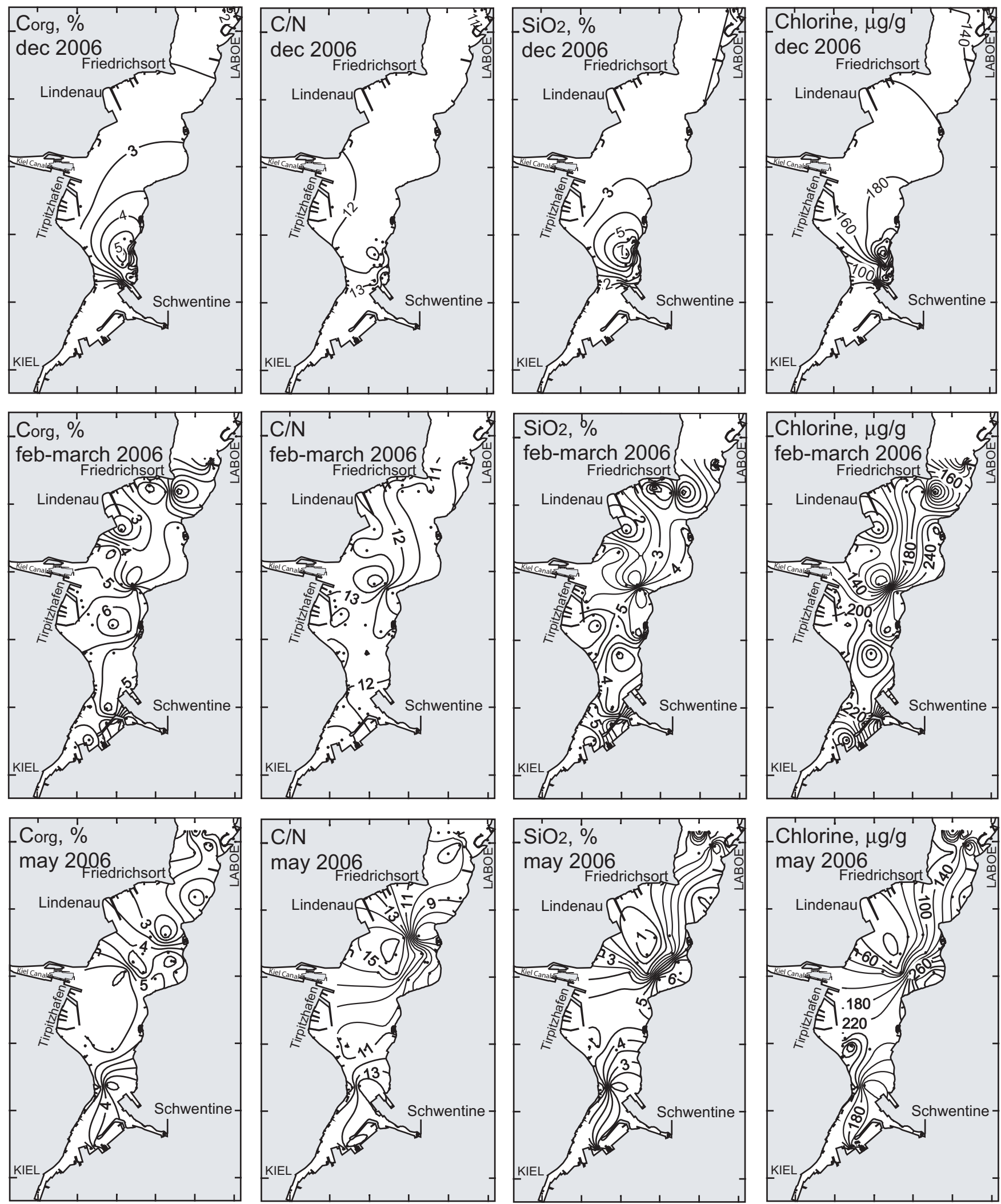

Fig. 2. Seasonal distribution of organic carbon (\%), biogenic silica (wt.\%) and chlorine (note: $\mu \mathrm{g} / \mathrm{g}$ instead of $\mathrm{ng} / \mathrm{g}$ by other authors) in Kiel Fjord. Sampling stations are shown here as black dots. 

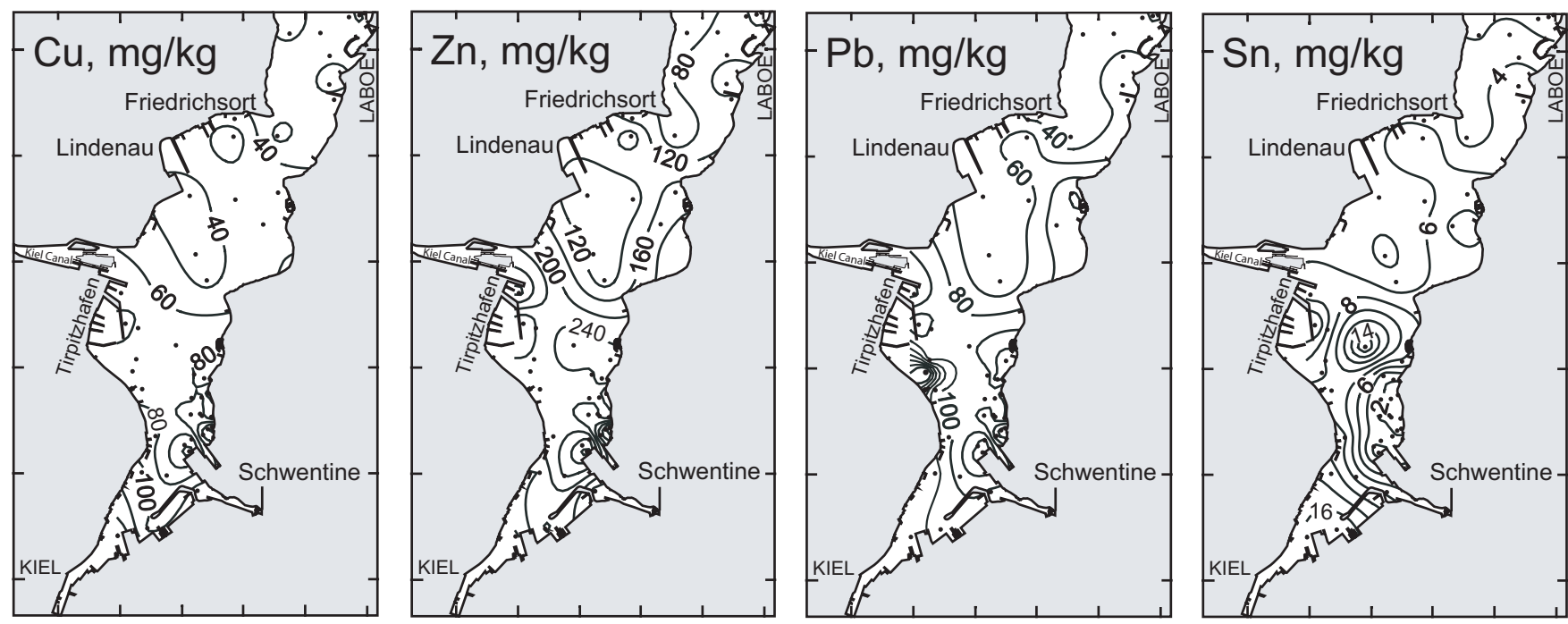

Fig. 3. Trace metals $(\mathrm{Cu}, \mathrm{Zn}, \mathrm{Pb}, \mathrm{Sn})$ distribution in Kiel Fjord.

Table 1. Mean (range) concentrations of trace metals $(\mathrm{Cu}, \mathrm{Zn}, \mathrm{Sn}, \mathrm{Pb}, \mathrm{mg} / \mathrm{kg})$ in the surface sediments of Kiel Fjord and their correlation with organic carbon and sand content, number of samples $n=53$.

\begin{tabular}{lccc}
\hline $\begin{array}{l}\text { Trace metals, } \\
\mathrm{mg} / \mathrm{kg}\end{array}$ & $\begin{array}{c}\text { Kiel Fjord, } \\
\text { mean (range) }\end{array}$ & $\begin{array}{c}\text { Correlation coefficient }(r) \\
\text { with } \mathrm{C}_{\text {org }}, \%\end{array}$ & $\begin{array}{c}\text { Correlation coefficient }(r) \\
\text { with sand content, \% }\end{array}$ \\
\hline $\mathrm{Cu}$ & $62.3(1.79-162)$ & 0.726 & -0.581 \\
$\mathrm{Zn}$ & $185(11.2-434)$ & 0.770 & -0.621 \\
$\mathrm{Sn}$ & $4.97(0.24-18.4)$ & 0.549 & -0.404 \\
$\mathrm{~Pb}$ & $118(6.81-260)$ & $0.675(n=52)$ & $-0.579(n=52)$ \\
\hline
\end{tabular}

generally higher in March than in December. The spatial distribution of chlorine concentrations was irregular. In December and February, the highest concentrations were observed in the innermost fjord, while in March and May the chlorine levels were elevated towards the outer fjord. As chlorine content is a proxy for productivity (Harris et al., 1996), this pattern seems to depend on the development of the spring bloom, sequential growth of different algal groups and changes in hydrographical conditions (Graf et al., 1982) as well as terrigenous input. The ratio of chlorophyll- $a$ to phaeopigments generally increased from February to May, which infers a flux of fresh organic matter to the sea floor (Greiser and Faubel, 1988; Reuss et al., 2005).

\subsection{Trace metals pollution}

The concentrations of copper, zinc, tin and lead in surface sediments of Kiel Fjord show a high variability (Table 1). With a sample thickness of one centimeter and presumable sedimentation rate in Kiel Fjord about $1 \mathrm{~mm}$ per year (Erlenkeuser et al., 1979; Balzer et al., 1987), one has to keep in mind that the trace metal concentrations present an average over the last 10 years. The concentrations are signifi- cantly positively correlated with the $\mathrm{C}_{\text {org }}$ contents and negatively correlated with the sand content. The correlation suggests that most of the trace metals are bound to organic matter, that they accumulate in muddy sediments, and that they are winnowed from of sandy sediments. In fact, elevated metal levels were recorded in the innermost and central fjord (Fig. 3). Moreover, exceptionally high metal concentrations were found in surface sediments close to Lindenau shipyards at Friedrichsort, and at Tirpitzhafen Navy base.

The long history of human impact in Kiel Fjord suggests that metal concentrations are substantially higher than the regional background (HELCOM, 1993). Except in the innermost fjord, trace metal concentrations are well in the range of values reported from elsewhere in Kiel Bight for the years 1999 to 2004 (Leipe et al., 1998; Haarich et al., 2003; Pohl et al., 2005).

Nonetheless, a trace metal study from a sediment core from Kiel Bight demonstrated that the metal concentrations systematically increased since the 1830s and reached maximum in 1950-1970s (Erlenkeuser et al., 1974). The youngest $\mathrm{Cu}, \mathrm{Zn}$ and $\mathrm{Pb}$ contents were estimated as 70, 230 and $80 \mathrm{mg} / \mathrm{kg}$, respectively. We found the average values of 62 , 

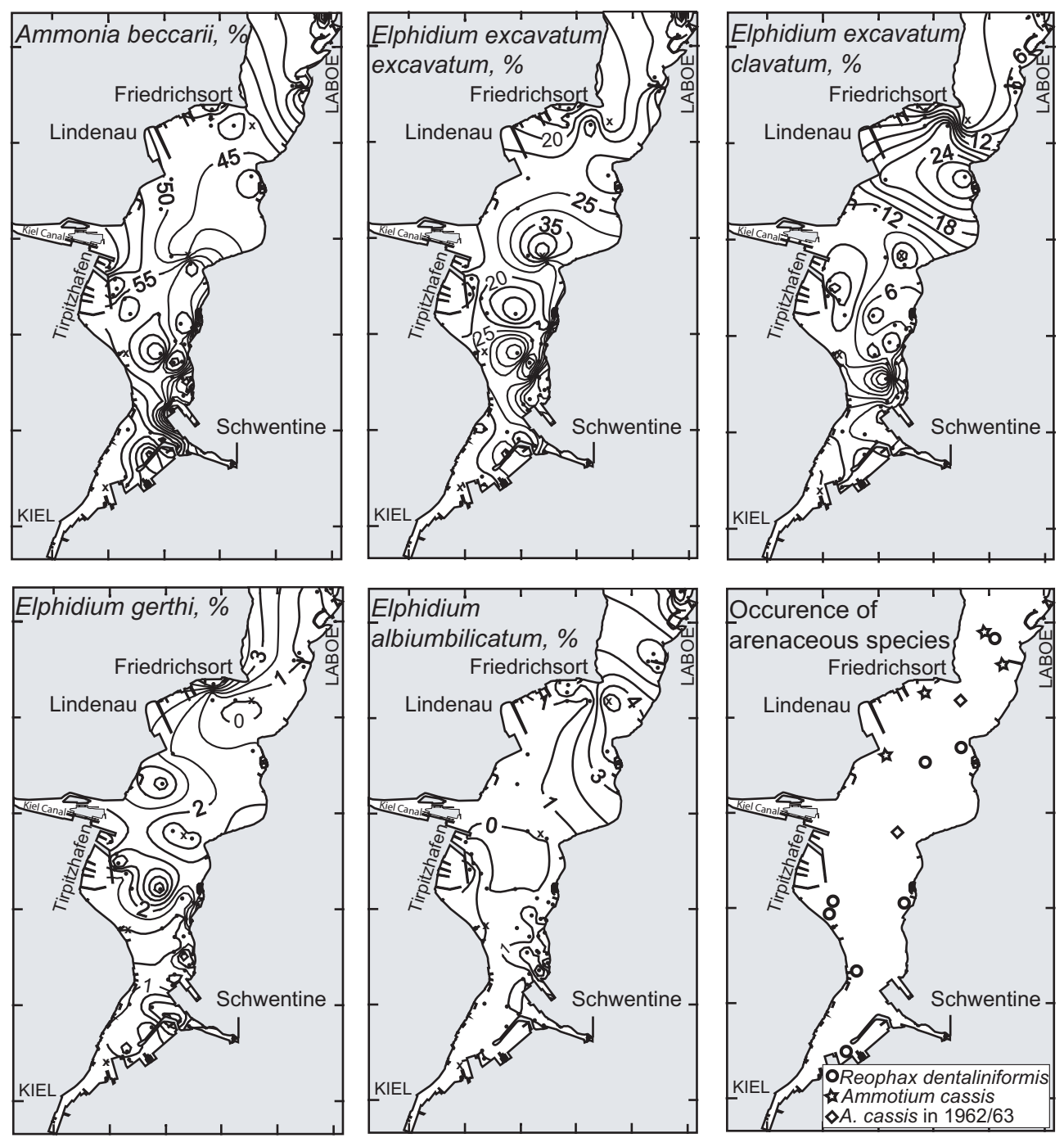

Fig. 4. Foraminiferal relative abundances and test abnormalities percentage in Kiel Fjord, here X indicates the stations revisited after Lutze (1965).

185 and $118 \mathrm{mg} / \mathrm{kg} \mathrm{Cu}, \mathrm{Zn}$ and $\mathrm{Pb}$. As such, no significant changes in heavy metal concentrations took place during last 40 years. To the north of Kiel Canal, we found even lower concentrations than in the 1960 s, presumably referring to environmental protection measures, in particular, a banning of lead additives in gasoline during the last decades. This may explain the today's low concentrations of lead in Kiel Fjord keeping in mind that its main sources in the Baltic region are atmospheric input and surface runoff (Brügmann, 1996). Tin concentrations were not reported in early investigations. In Kiel Fjord the concentration of tin in the sediment fraction $<2000 \mu \mathrm{m}$ (LANU archive: Ostseemonitoring Programme) was $24 \mathrm{mg} / \mathrm{kg}$ in 2004 whereas in other fjords and bays of Kiel Bight it varied from 4 to $17 \mathrm{mg} / \mathrm{kg}$. Our measurements range from 0.2 to $18 \mathrm{mg} / \mathrm{kg}$ and confirm the elevated levels in the inner fjord. This can be related to sport harbours and shipyards despite the recent restriction of tin-containing antifouling paints (IMO, 2005).

4.6 Foraminiferal population density and species composition

The foraminiferal population density in Kiel Fjord ranged from 3 to 4895 ind. $/ 10 \mathrm{~cm}^{3}$, on average 200 to $400 \mathrm{ind} / 10 \mathrm{~cm}^{3}$. The living benthic foraminiferal communities were dominated by Ammonia beccarii (52\% on average) and subspecies of Elphidium excavatum (together $44 \%$ on average). Elphidium incertum, Elphidium albiumbilicatum and Elphidium gerthi were common (5.3 and 3\% on average). Ammotium cassis, Reophax dentaliniformis regularis, Elphidium williamsoni, and Elphidium gunteri were rare (maximal 2\%). The stations with predominance of $A$. beccarii generally have a lower abundance 


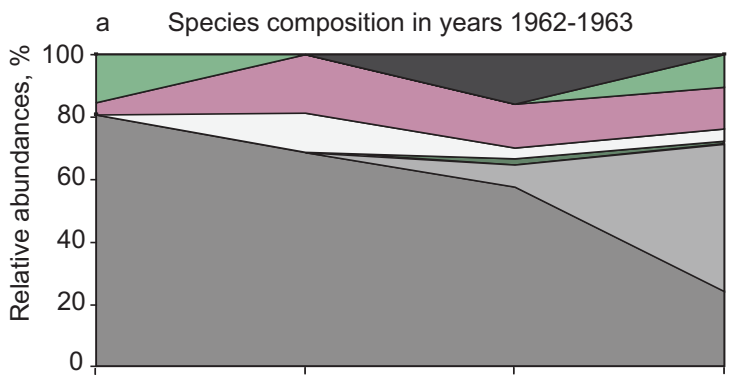

b Species composition published in Lutze (1965)

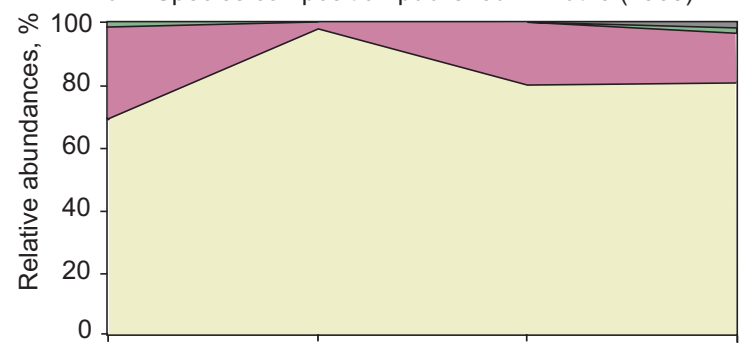

d Population density in years 1962-1963 vs. 2006

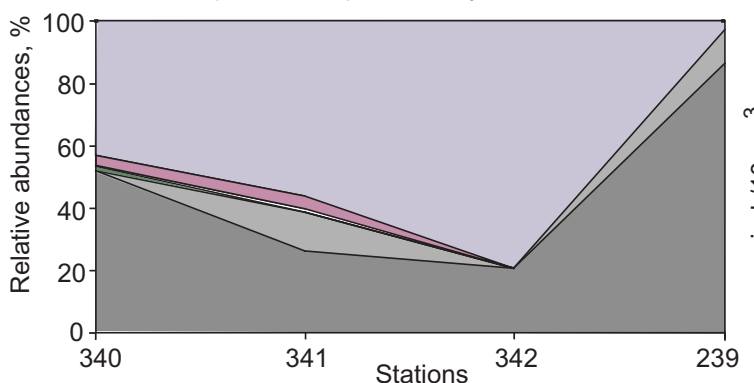

$\square$ E. excavatum excavatum

$\square$ E. albiumbilicatum

$\square$ A. cassis

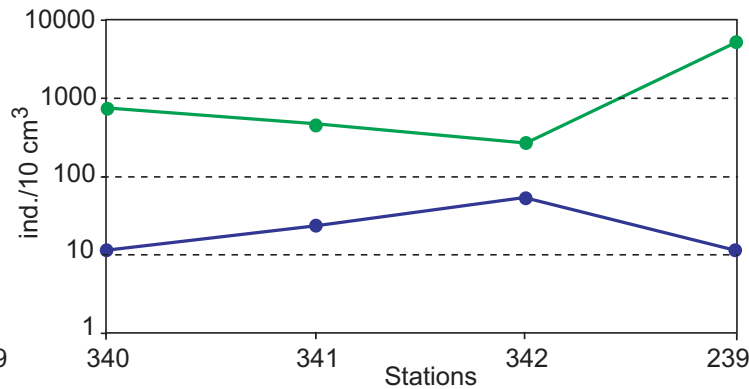

$\square$ E. gerthi

$\square$ A. beccarii

$\square$ E. excavatum subspecies

Fig. 5. The species composition in re-examined samples from Lutze collection taken in 1962-1963 (a), described by Lutze himself (b) and at stations revisited after Lutze in February 2006 (c). Panel (d) shows the changes in population density (log scale) since 1960s (Lutze, 1965).

of E. excavatum excavatum and vice versa (Supplementary material: http://www.electronic-earth.net/3/37/2008/ ee-3-37-2008-supplement.pdf, Table 2, Plate 1). We do not recognize any physical, biological or chemical parameter that would explain this spatial change in dominance. But we cannot entirely rule out, that these species occupy different ecological niches. As such, we can presume a substitution of these species. E. incertum and E. albiumbilicatum co-occurred with moderate abundances to both sides of Friedrichsort Sound. E. gerthi and E. williamsoni were recorded in shallow and near-shore samples (Fig. 4).

The arenaceous species $R$. dentaliniformis regularis and A. cassis were recorded only sporadically in our samples. The situation was quite different in the 1960s, for instance, Lutze (1965) reported A. cassis with up to $2 \%$ of the living fauna in Kiel Fjord (Fig. 5b). We re-examined 4 of Lutze's samples curated at the Institute of Geosciences (University of Kiel) and revisited his stations in February 2006 (Fig. 5a, c). The samples taken in 2006 revealed a 5 to 445 -fold increase of foraminiferal population densities as compared to the 1960s. We also did not find A. cassis. This species was common elsewhere in Kiel Bight until the mid 1990s (Schönfeld and Numberger, 2007a). Our results infer that A. cassis has apparently disappeared in the 2000s from Kiel Fjord too, and that it has been presumably replaced by A. beccarii.
Positive correlations of population density with biogenic silica $(r=0.475 ; n=21)$ and chlorophyll- $a(r=0.600 ; n=21)$ were found for samples taken in December. This underpins the strong relationship of the availability of food, in particular diatoms, and foraminiferal population density (Altenbach, 1992; Schönfeld and Numberger, 2007b).

In order to reveal the stress response capability of the benthic foraminiferal fauna, we calculated the ration of the tolerant species $A$. beccarii vs. the specialized $E$. excavatum (A/E Index), firstly described by Sen Gupta et al. (1996) as a proxy of hypoxia. The highest $\mathrm{A} / \mathrm{E}$ values were found in the central part of Kiel Fjord. They coincide with high $\mathrm{C}_{\text {org }}(7 \%)$ and tin concentrations $(18 \mathrm{mg} / \mathrm{kg})$.

In the inner part of Kiel Fjord, we recorded high frequencies of test abnormalities (up to $17 \%$ ). This is considerably higher than the typical value of $1 \%$ under natural undisturbed conditions (Alve, 1991; Yanko et al., 1999). The majority of abnormal tests were observed in A. beccarii. A high number of test abnormalities preferentially occurred in the inner fjord, where the highest trace metal levels were marked.

E. albiumbilicatum has been described as a typical shallow-water species (Lutze, 1965). Here, it inhabits the transitional area of Friedrichsort Sound where sandy sediments prevailed. The high water turbulences seemingly prevent the accumulation of organic matter bound trace metals here. On the other hand, it was suggested that species living in turbulent waters develop spines (Boltovskoy et al., 1991). 
Tests of E. albiumbilicatum possess the numerous pustules in apertural and umbilical areas making the test surface rough and enabling this species to withstand the higher water turbulences in this sound.

The species composition of dead assemblages at stations revisited after Lutze was the same as the living assemblages. Lutze (1965) reported that thanatocoenoses in the 1960s also resembled the living communities. In 2006, the living:dead ratios varied from 0.3 in the inner part to 3.2 in the outer Kiel Fjord, which is on average 5 times higher, than it was in the 1960s (http://www.electronic-earth.net/3/37/2008/ ee-3-37-2008-supplement.pdf, Table 3).

The remarkable increase in population densities as compared to previous studies in Kiel Fjord arises a question: why living foraminifera became so abundant since the 1960 s, especially in the presence of trace metals? According to Yanko et al. (1999), some foraminifera might respond positively when the environmental impact is continuous. On the other hand, there are no data on trace metal concentrations in Kiel Fjord from the 1960s and therefore one cannot conclude that trace metals are the only factor that is responsible for the observed changes. Moreover, after the setup of sewage treatment plants and strict environmental protective politics in the 1990s (e.g. Danish Action Plan (I); HELCOM), which caused a decrease of industrial discharges and agricultural load, a general decrease of nutrient inputs and stabilization of oxygen levels in the SW Baltic took place (Nausch et al., 2003a, 2004). Despite the slight decline in nutrient levels since the mid 1990s, an increase of primary production by roughly $40 \%$ during the past 30 years has been suggested for the western Baltic Sea (Wassmann, 1990; Schönfeld and Numberger, 2007a). Provided this is applicable for Kiel Fjord too, even a doubling in primary production can not explain a 67 -fold increase in foraminiferal population densities from $23 \mathrm{ind} / 10 \mathrm{~cm}^{3}$ on average in 1963 to $1582 \mathrm{ind} / 10 \mathrm{~cm}^{3}$ on average in 2005 and 2006.

\subsection{Re-examination of Lutze's material}

Differences in results shown at Fig. 5a and b may refer to discrepancy in taxonomy, sampling seasons, size fractions ( $>63 \mu \mathrm{m}$ in this study and $>100 \mu \mathrm{m}$ by G.-F. Lutze) and study of the whole samples (in 2006) vs. concentrates (1960s). Figure 5b shows E. excavatum subspecies, lumped together in 1960s, as the dominant elements of the living fauna. E. incertum had higher abundances, whereas A. cassis and $R$. dentaliniformis were rare. Lutze did not report $E$. albiumbilicatum and E. gerthi, which we found in his samples. Apparently he recognized both species as variants of $E$. excavatum. Lutze's sampling campaign started in spring 1962 and continued until fall 1963. Regarding the difference in sample numbering (342 vs. 239), it well might be that sampling in the 1960s also comprised several seasons per year, as we did in the current study. Concerning the differences in size fractions, it was shown that there were no living speci- mens smaller than $80 \mu \mathrm{m}$ observed in the western Baltic Sea (Schönfeld and Numberger, 2007a: p. 85). Therefore it is unlikely that G.-F. Lutze missed or washed away a significant proportion of the fauna. Most residues of Lutze' samples contained a very few or no living specimens whereas the respective flotation concentrates were very rich. Therefore, even if Lutze examined only concentrates but not the whole samples, his results on the population density would not differ by two orders of magnitude to the results we obtained in our 2006 survey. Thus, we finally consider the differences in methods in this study comparing to the 1960 s to be of minor influence on the final result.

\subsection{Invasion and opportunistic behaviour of Ammonia beccarii}

A. beccarii has an ubiquitous distribution in the Kiel Fjord whereas both $E$. excavatum subspecies show avoidance of the central fjord with silty sediments enriched in $\mathrm{C}_{\text {org }}$ and tin. In the North Sea, Sharifi (1991) described E. excavatum as more frequent than A. beccarii in sediments polluted by Zn. According to Alve (1995), abundant and geographically widespread species are to be considered as most tolerant to environmental pollution. A. beccarii is commonly frequent in coastal and paralic environments (e.g. Stouff et al., 1999a, b). Taking all this into account, we consider that the main reason why A. beccarii is so abundant in Kiel Fjord, its opportunistic behaviour and high potential to survive under high input of nutrients and trace metal concentrations.

\subsection{Disappearance of Ammotium cassis}

Sample PO220-37-2 taken in the Kiel Bight in 1996 had 90\% of $A$. cassis, but did not contain any calcareous foraminifera. It may well be, that due to bad storage conditions, all the calcareous tests were dissolved in this sample. For this reason, we revisited station PO220-37-2 in December 2005 but we did not find living A. cassis any more. Lutze (1965) stated that foraminifera in the Baltic Sea are mainly salinity and temperature dependant, and that $A$. cassis is adapted to a strong halocline between surface and deep waters in Kiel Bight. Schönfeld and Numberger (2007a) suggested cyclic changes of $A$. cassis abundances depending on saltwater inbursts in the Kiel Bight and high salinity contrasts between surface and deep waters. As we observed only isolated specimens in some places, the inner Kiel Fjord is currently almost unpopulated by A. cassis. This pattern may be due to the fact that the inner fjord is shallower, more closed and less saline than the open Kiel Bight. As such, the deep boundary layer, which is a necessary condition for nutrition of A. cassis, cannot establish in Kiel Fjord (Olsson, 1976).

It is conceivable that with faunal change from very large A. cassis to much smaller A. beccarii, the total biomass might decreased. However, as the population density increased significantly since 1960 s, we may assume that biomass today 
is higher than it was in 1960s and 1990s, when Ammotium cassis was abundant in the Kiel Bight.

\section{Conclusions}

The results of the present study showed that labile organic compounds (biogenic opal, chlorines, $\mathrm{C}_{\text {org }}$ ) in sediments of the Kiel Fjord were subjected to a strong seasonal variability. Their concentrations are significantly higher in springtime. The spatial distribution of labile organic compounds is mainly determined by sediment type. Generally, the levels of concentrations of biogenic compounds are comparable to those reported from the open Kiel Bight. Markedly low levels of food in Friedrichsort Sound establish quite unfavourable conditions for many benthic foraminiferal species. The surface sediment pollution by copper, zinc, tin and lead principally could be considered as moderate because the levels of metals are comparable to those elsewhere in the Baltic Sea. Nevertheless the inner Kiel Fjord is distinguished by a high load of heavy metals. The high tin concentrations in surface sediments apparently depend on its accumulation in muddy sediments for previous decades.

The analysis of foraminiferal population density shows a patchy distribution and a response to food availability, which is depicted by $\mathrm{SiO}_{2}$ and Chl- $a$ in the sediments. The strong increase of population density since the 1960 s remains enigmatic. It cannot be attributed to an increase in organic matter supply and a slight reduction of pollution. Furthermore, we observed significant changes in foraminiferal species composition in 2005-2006 as compared to the 1960s. The stresstolerant species $A$. beccarii invaded Kiel Fjord. We suppose that this species is highly opportunistic and can tolerate elevated levels of nutrients and trace metals. E. albiumbilicatum apparently is able to withstand the higher water turbulences and therefore inhabits the transitional area of Friedrichsort Sound. Unfavourable salinity conditions in the Kiel Bight and absence of a deep halocline in Kiel Fjord might have caused the disappearance of $A$. cassis during the past decades.

\section{Appendix A}

\section{Faunal reference list}

Ammonia beccarii $($ Linné $)=$ Nautilus beccarii

Linné (1758); Schönfeld and Numberger (2007a, p. 52, pl. 1, Fig. 2). (Note: Ammonia tepida; De Noijer, 2007, p. 24, pl. 1, Fig. A; molecular types of Ammonia T1 and T2, Hayward et al., 2004, p. 256-258, pl. II-IV).

Ammotium cassis (Parker) = Lituola cassis

Parker (1870); Frenzel et al. (2005, p. 75, Fig. 4., no. 3).

Elphidium albiumbilicatum (Weiss) = Nonion pauciloculum Cushman subsp. albiumbilicatum

Weiss (1954); Frenzel et al. (2005, p. 73, Fig. 2., no. 10);
Schönfeld and Numberger (2007a, p. 52, pl. 1, Fig. 4). (Note: Elphidium asklundi Brotzen, 1943, of Lutze, 1965; Cribroelphidium albiumbilicatum of Frenzel, 2005).

Elphidium excavatum excavatum (Terquem) = Polistomella excavata

Terquem (1875), Miller et al. (1982, p. 127, pl. 1, Figs. 1112); Schönfeld and Numberger (2007a, p. 52, pl. 1, Figs. 1213).

Elphidium excavatum clavatum

Cushman (1930); Miller et al. (1982, p. 127, pl. 1, Fig. 8); Schönfeld and Numberger (2007a, p. 52, pl. 1, Figs. 7-9).

Elphidium gerthi

van Voorthuysen (1957); Lutze (1965, p. 159, pl. 15, Fig. 45)

(Note: Cribrononion cf. gerthi of author).

Elphidium gunteri

Cole (1931); Frenzel et al. (2005, p. 73, Fig. 2., no. 2) (Note: Cribroelphidium gunteri of authors).

Elphidium incertum (Williamson) = Polystomella umbilicatula (Walker) var. incerta

Williamson (1858); Schönfeld and Numberger (2007a, p. 52, pl. 1, Figs. 5-6).

Elphidium williamsoni

Haynes (1973) (Note: Cribrononion cf. alvarezianum Orbigny, 1839 of Lutze, 1965; Frenzel et al., 2005, p. 73, Fig. 2., no. 8) (Note: Cribroelphidium williamsoni of authors).

Reophax dentainiformis $f$. regularis Höglund (1947); Schönfeld and Numberger (2007a, p. 52, pl. 1, Fig. 11).

Acknowledgements. The authors thank Wolfgang Kuhnt who provided access to original G.-F. Lutze's samples at the Institute of Geosciences at Kiel University and samples from RV Poseidon cruise 220. We are also grateful to Joachim Voß and Thorkild Petenati (LANU), who made the unpublished data of LANU archives available. We kindly appreciate the technical assistance of Jutta Heinze, Anna Kolevica, Udo Laurer (IFM-Geomar), Ute Schuldt and Ulrike Westernströer (Institute for Geosciences, Kiel). We acknowledge the crew of RV Polarfuchs Holger Meyer and Helmut Schramm for help with sampling. Our sincere thanks go to Elisabeth Alve (University of Oslo) for her valuable advice on early stage of this study. We are grateful to Frans Jorissen and Peter Frenzel for constructive review comments. This study was funded by German Academical Exchange Service (DAAD) and the Leibniz Award DFG DU 129-33 of W.-Ch. Dullo.

Edited by: S. Spezzaferri

\section{References}

Altenbach, A. V.: Short term processes and patterns in foraminiferal response to organic flux rates, Mar. Micropaleontol., 19, 119129, 1992.

Alve, E.: Benthic foraminifera in sediment cores reflecting heavy metal pollution in Soerfjord, Western Norway, J. Foramin. Res., 21, 1-19, 1991. 
Alve, E.: Benthic foraminiferal responses to estuarine pollution: a review, J. Foramin. Res., 25, 190-203, 1995.

Alve, E. and Murray, J. W.: Marginal marine environments of the Skagerrak and Kattegat: a baseline study of living (stained) benthic foraminifera, Paleogeogr. Paleoclimatol. Palaeoecol., 146, 171-193, 1999.

Alve, E. and Olsgardt, F.: Benthic foraminiferal colonisation in experiments with copper-contaminated sediments, J. Foram. Res., 29, 186-195, 1999.

Balzer, W., Erlenkeuser, H., Hartmann, M., Müller, P. J., and Pollehne, F.: Diagenesis and exchange processes at the benthic boundary, Coastal and Estuarine Studies, 13, 111-161, 1987.

Bergin, F., Kucuksezgin, F., Uluturhan, E., Barut, I. F., Meric, E., Avsar, N., and Nazik, A.: The response of benthic foraminifera and ostracoda to heavy metal pollution in Gulf of Izmir (Eastern Aegean Sea), Estuar. Coast. Shelf S., 66, 368-386, 2006.

Bernardez, P., Frances, G., and Prego, R.: Benthic-pelagic coupling and postdepositional processes as revealed by the distribution of opal in sediments: The case of the Ria de Vigo (NW Iberian Peninsula), Estuar. Coast. Shelf S., 68, 271-281, 2006.

Boltovskoy, E., Scott, D. B., and Medioli, F. S.: Morphological variations of benthic foraminiferal tests in response to changes in ecological parameters: a review, J. Paleontol., 65, 175-185, 1991.

Bradshaw, J.: Laboratory studies on the rate of growth of the foraminifer "Streblus beccarri (Linne) var. tepida (Cushman)", J. Paleontol., 31, 1138-1147, 1957.

Bradshaw, J.: Laboratory experiments on the ecology of foraminifera, Contributions from the Cushman Foundation for Foraminiferal Research, 7(3), 87-106, 1961.

Brügmann, L.: Quellen und regionale Verteilung von Schwermetallen im Wasser und Sediment, in: Warnsignale aus der Ostsee, edited by: Lozan, J. L, Lampe, R., Matthäus, W., Rachor., E., Rumohr, H., and von Westernhagen, H., Parey Buchverlag, Berlin, 74-79, 1996.

Burone, L., Venturini, N., Sprechmann, P., Valente, P., and Muniz, P.: Foraminiferal responses to polluted sediments in the Montevideo coastal zone, Uruguay, Mar. Pollut. B., 52, 61-73, 2006.

Debenay, J.-P., Tsakiridis, E., Soulard, R., and Grossel, H.: Factors determining the distribution of foraminiferal assemblages in Port Joinville Harbour (lle d'Yeu, France): the influence of pollution, Mar. Micropaleontol., 43, 75-118, 2001.

De Nooijer, L.: Shallow-water benthic foraminifera as proxy for natural versus human-induced environmental change 2007, Geologica Ultraiectina, Mededelingen van de Faculteit Geowetenschappen Universiteit Utrecht, Utrecht, Netherlands, 272, 152 pp., 2007.

Di Leonardo, R., Bellanca, A., Capotondi, L., Cundy, A., and Neri, R.: Possible impacts of $\mathrm{Hg}$ and $\mathrm{PAH}$ contamination on benthic foraminiferal assemblages: an example from the Sicilian coast, central Mediterranean, Sci. Total Environ., 388, 168-183, 2007.

Ellison, R., Broome, R., and Ogilvie, R.: Foraminiferal response to trace metal contamination in the Patapsco River and Baltimore Harbour, Maryland, Mar. Pollut. B., 17, 419-423, 1986.

Erlenkeuser, H., Suess, E., and Willkomm, H.: Industrialization affects heavy metal and carbon isotope concentrations in recent Baltic Sea sediments, Geochim. Cosmochim. Acta, 38, 823-842, 1974.

Ernst, S. R., Morvan, J., Geslin, E., Le Bihan, A., and Jorissen, F. J.:
Benthic foraminiferal response to experimentally induced Erika oil pollution, Mar. Micropaleontol., 61, 76-93, 2006.

Frenzel, P., Tech, T., and Bartholdy, J.: Checklist and annotated bibliography of Recent Foraminiferida from the German Baltic Sea coast, in: Methods and applications in micropaleontology, edited by: Tyszka, J., Studia Geologica Polonica, 124, 67-86, 2005.

Garbe-Schönberg, C. D.: Simultaneous determination of 37 trace elements in 28 international rock standards by ICP-MS, Geostandard Newslett., 17, 81-93, 1993.

Gerlach, S. (Ed.): Oxygen depletion 1980-1983 in coastal waters of the Federal Republic of Germany, Berichte aus dem Institut fur Meereskunde an der Christian-Albrechts-Universität Kiel, 130, 97 pp., 1984.

Gerlach, S.: Nitrogen, phosphorus, plankton and oxygen deficiency in the German Bight and the Kiel Bay, Kieler Meeresforschungen, Sonderheft 7, 341 pp., 1990.

Gerlach, S. A.: Ökologische Veränderungen in der Kieler Bucht, in: Warnsignale aus der Ostsee, edited by: Lozan, J. L., Lampe, R., Matthäus, W., Rachor, E., Rumohr, H., and von Westernhagen, H., Parey Buchverlag, Berlin, 259-292, 1996.

Graf, G., Bengtsson, W., Diesner, U., Sehulz, R., and Theede, H.: Benthic Response to Sedimentation of a Spring Phytoplankton Bloom: Process and Budget, Mar. Biol., 67, 201-208, 1982.

Greiser, N. and Faubel, A.: Biotic factors, in: Introduction to the study of meiofauna, edited by: Higgins, R. P. and Thiel, H., Smithsonian Institution Press, London, 79-114, 1998.

Gustafsson, M. and Nordberg, K.: Living (stained) benthic foraminiferal response to primary production and hydrography in the deepest part of the Gullmar Fjord, Swedish west coast, with comparison to Hoeglund's 1927 material, J. Foramin. Res., 31(1), 2-11, 2001.

Haarich, M., Pohl, C., Leipe, T., Grünwald, K., Bachor, A., v. Weber, M., Petenati, T., Schröter-Kermani, C., Jansen, W., and Bladt, A.: Anorganische Schadstoffe, in: Meeresumwelt 19992002, Ostsee, Bund-Länder-Messprogramm für die Meeresumwelt von Nord- und Ostsee, Kiel, 167-194, 2003.

Harris, P. G., Zhao, M., Rosell-Melé, A., Thiedemann, R., Sarnthein, M., and Mexwell, J.-R.: Chlorin accumulation rate as a proxy Quaternary marine primary productivity, Nature, 383, 6365, 1996.

Hayward, B. W., Holzmann, M., Grenfell, H. R., Pawlowski, J., and Triggs, C. M.: Morphological distinction of molecular types in Ammonia - towards a taxonomic revision of the world's most commonly misidentified foraminifera, Mar. Micropaleontol., 50, 237-271, 2004.

HELCOM: First Assessment of the State of the Coastal Waters of the Baltic Sea, Baltic Sea Environmental Proceedings 54, Helsinki, 166 pp., 1993.

IMO: Anti-Fouling Systems. International Convention on the Control of Harmful Anti-Fouling Systems on Ships, 2005 edition, London, IMO, available online at: http://www.imo.org/ Conventions/mainframe.asp?topic_id=529, 2005.

Kallmeyer, T.: Probleme der Abwasserentsorgung und Gewässerbelastung aus historischer Sicht am Beispiel Kiels und der Kieler Förde, Diplomarbeit, Kiel University, Germany, 76 pp., 1997.

LANU: Organozinnverbindungen in Hafensedimenten und biologische Effekte, Untersuchungen in Sedimenten und an 
der Strandschnecke (Littorina littorea L.) in schleswigholsteinischen Küstengewässern, Landesamt für Natur und Umwelt des Landes Schleswig-Holstein, Open Rep., 55 pp., available online at: http://www.lanu.landsh.de, 2001.

LANU: Sauerstoffmangel in der westlichen Ostsee im Sommer und Herbst 2002, in: Jahresbericht 2002, Landesamt für Natur und Umwelt des Landes Schleswig-Holstein, Flintbek, 133-139, 2003.

Le Cadre, V., Debenay, J.-P., and Lesourd, M.: Low pH effects on Ammonia beccarii test deformation: implications for using test deformations as a pollution indicator, J. Foramin. Res., 33, 1-9, 2003.

Le Cadre, V. and Debenay, J. P.: Morphological and cytological responses of Ammonia (foraminifera) to copper contamination: Implication for the use of foraminifera as bioindicators of pollution, Environ. Pollut., 143, 304-317, 2006.

Lehmann, G. and Röttger, R.: Techniques for the concentration of foraminifera from coastal salt meadow sediments, J. Micropaleontol., 16, 144, 1997.

Leipe, T., Tauber, F., Brügmann, L., Irion, G., and Hennings, U.: Schwermetallverteilung in Oberflächensedimenten der westlichen Ostsee (Arkonabecken, Mecklenburger/Lübecker Bucht and Kieler Bucht), Meyniana, 50, 137-154, 1998.

Lutze, G.: Zur Foraminiferen-Fauna der Ostsee, Meyniana, 15, 75142, 1965.

Miller, A. A. L., Scott, D. B., and Medioli, F.: Elphidium excavatum (Terquem): ecophenotypic versus subspecific variation, J. Foramin. Res., 12, 116-144, 1982.

Moodley, L. and Hess, Ch.: Tolerance of infaunal benthic foraminifera for low and high oxygen concentrations, Biol. B., 183, 94-98, 1992.

Murray, J. W. and Bowser, S.: Mortality, protoplasm decay rate, and reliability of staining techniques to recognize "living" foraminifera: a review, J. Foramin. Res., 30, 66-70, 2000.

Müller, P. J. and Schneider, R.: An automated leaching method for the determination of opal in sediments and particulate matter, Deep-Sea Res., Part 1, Oceanogr Res Pap, 40, 425-444, 1993.

Möbius, K.: Bruchstücke einer Rhizopodenfauna der Kieler Bucht, Physikalische Abhandlungen der Königlichen Akademie der Wissenschaften zu Berlin, 1-31, 1888.

Nausch, G., Matthäus, W., and Feistel, R.: Hydrographical and hydrochemical conditions in the Gotland Deep are between 1992 and 2003, Oceanologia, 45, 557-569, 2003a.

Nausch, G., Feistel, R., Lass, H. U., Nagel, K., and Siegel, H.: Hydrographisch-chemische Zustandseinschätzung der Ostsee 2002, Meereswissenschaftliche Berichte, Warnemünde, 55, 2003 b.

Nausch, G., Feistel, R., Lass, H. U., Nagel, K., and Sielgel, H.: Hydrographisch-chemische Zustandseinschätzung der Ostsee 2003, Meereswissenschaftliche Berichte, 59, 1-79, 2004.

Olsson, I.: Distribution and ecology of foraminiferan Ammotium cassis (Parker) in some Swedish estuaries, Zoon, 4, 137-147, 1976.

Pertillä, M. (Ed.): Contaminants in the Baltic Sea sediments. Results of the 1993 ICES/HELCOM Sediment baseline study, MERI - Rep. Series of the Finnish Institute of Marine Research, 50, 69 pp., 2003.

Pohl, C., Hennings, U., and Leipe, T.: Ostsee-Monitoring die Schwermetall-Situation in der Ostsee im Jahre 2004, IOW,
Warnemünde, 36 pp., 2005.

Rathburn, A. E., Perez, M. E., and Lange, C. B.: Benthic-pelagic coupling in the Southern California Bight: Relationship between sinking organic material, diatoms and benthic foraminifera, Mar. Micropaleontol., 43, 261-271, 2001.

Reuss, N., Conley, D. J., and Bianchi, T. S.: Preservation conditions and the use of sediment pigments as a tool for recent ecological reconstruction in four Northern European estuaries, Mar. Chem., 95(3-4), 283-302, 2005.

Revsbech, N. P.: An oxygen microelectrode with a guard cathode, Limnol. Oceanogr., 34, 472-476, 1989.

Rheinheimer, G.: Pollution in the Baltic Sea, Naturwissenschaften, 85, 318-329, 1998.

Rhumbler, L.: Rhizopoden der Kieler Bucht, gesammelt durch A. Remane, 1. Teil, Schriften des Naturwissenschaftlichen Vereins Schleswig-Holstein, 21, 143-194, 1935.

Rottgardt, D.: Mikropaläontologisch wichtige Bestandteile rezenter brackischer Sedimente an den Küsten Schleswig-Holsteins, Meyniana, 1, 169-228, 1952.

Samir, A. M. and El-Din, A. B.: Benthic foraminiferal assemblages and morphological abnormalities as pollution proxies in two Egyptian bays, Mar. Micropaleontol., 41, 193-127, 2001.

Schafer, C. T.: Distribution of foraminifera near pollution sources in Chaleur Bay, Water Air Soil Pollut., 2, 219-233, 1973.

Sharifi, A. R., Croudace, L. W., and Austin, R. L.: Benthic foraminiferids as pollution indicators in Southampton Water, southern England, United Kingdom, J. Micropaleontol., 10, 109$113,1991$.

Schiewer, U. and Gocke, K.: Ökologie der Bodden und Förden, in: Meereskunde der Ostsee, 2, edited by: Rheinheimer G., Springer Verlag, Berlin, 216-221, 1995.

Schönfeld, J. and Numberger, L.: Seasonal dynamics and decadal changes of benthic foraminiferal assemblages in the western Baltic (NW Europe), J. Micropaleontol., 26, 47-60, 2007a.

Schönfeld, J. and Numberger, L.: The benthic foraminiferal response to the 2004 spring bloom in the western Baltic Sea, Mar. Micropaleontol., 65, 78-95, 2007b.

Schulz, F.: Trendauswertung der stofflichen Belastung schleswigholsteinischer Fließgewässer, in: Landesamt für Natur und Umwelt Jahresbericht 1999, LANU, Flintbek, available online at: www.umweltdaten.landsh.de/nuis/upool/gesamt/jahrbe99/ Trendauswertung.pdf, 59-65, 2000.

Schwarzer, K. and Themann, S.: Sediment distribution and geological buildup of Kiel Fjord (Western Baltic Sea), Meyniana, 55, 91-115, 2003.

Sen Gupta, B. K., Turner, R. E., and Rabalais, N. N.: Seasonal oxygen depletion in continental shelf waters of Louisiana: Historical record of benthic foraminifers, Geology, 24, 227-230, 1996.

Senocak, T.: Schwermetalluntersuchung an Fischen der deutschen Ostseekäste (Kliesche, Limanda limanda; Flunder, Platichthys flesus; Hering Clupea harengus und Dorsch, Gadus morhua), Berichte aus dem Institut fur Meereskunde an der ChristianAlbrechts-Universität Kiel, 270, 177 pp., 1995.

Stouff, V., Debenay, J.-P., and Lesourd, M.: Origin of double and multiple tests in benthic foraminifera: observations in laboratory cultures, Mar. Micropaleontol., 36, 189-204, 1999a.

Stouff, V., Geslin, E., Debenay, J.-P., and Lesourd, M.: Origin of morphological abnormalities in Ammonia (Foraminifera): studies in laboratory and natural environments, J. Foramin. Res., 29, 
152-170, 1999b.

ter Jung, C.: Beitrag zum Schwermetallgehalts-Monitoring (Yn, $\mathrm{Cd}, \mathrm{Hg}, \mathrm{Cn}, \mathrm{Ag}, \mathrm{Pb}, \mathrm{Cr}, \mathrm{Ni}$ ) in Miesmuscheln an der schleswigholsteinischen Ostseeküste (1988-1989), Berichte aus dem Institut fur Meereskunde an der Christian-Albrechts-Universität Kiel, Kiel, 221, 89 pp., 1992.

Tomas, E., Gapotchenko, T., Varekamp, E. C., Mecray, E. L., and Buchholtz ten Brink, M. R.: Maps of benthic foraminiferal distribution and environmental changes in Long Island Sound between 1940s and 1990s, in: US Geological Survey Open-File Report 00-304, edited by: Paskevich, V. F. and Poppe, L. J., USGS, Woods Hole, MA, available online at: http://pubs.usgs.gov/of/ 2000/of00-304/htmldocs/chap09/index.htm, 2000.

Wasmund, N., Pollehne, F., Postel, L., Siegel, H., and Zettler, M. L.: Biologische Zustandseinschätzung der Ostsee im Jahre 2004, Meereswissenschaftliche Berichte 64, IOW, Warnemünde, 2005. Wasmund, N., Pollehne, F., Postel, L., Siegel, H., and Zettler, M. L.: Biologische Zustandseinschätzung der Ostsee im Jahre 2005, Meereswissenschaftliche Berichte 69, IOW, Warnemünde, 2006.
Wassmann, P.: Relationship between primary and export production in the boreal coastal zone of the North Atlantic, Limnol. Oceanogr., 35(2), 464-471, 1990.

Watkins, J. G.: Foraminiferal ecology around the Orange County, California, ocean sewer outfall, Micropaleontology, 7, 199-206, 1961.

Wefer, G.: Umwelt, Produktion und Sedimentation benthischer Foraminiferen in der westlichen Ostsee. Reports Sonderforschungsbereich 95 Wechselwirkung Meer-Meeresboden, 14, 1-103, 1976.

Yanko, V., Ahmad, M., and Kaminski, M.: Morphological deformities of benthic foraminiferal tests in response to pollution by heavy metals: implications for pollution monitoring, J. Foramin. Res., 28, 177-200, 1998.

Yanko, V., Arnold, A. J., and Parker, W. C.: Effects of marine pollution on benthic Foraminifera, in: Modern Foraminifera, edited by: Sen Gupta, B. K., Kluwer Academic Publishers, MA, 217235, 1999. 